\title{
Protocol on the Statute of the African Court of Justice and Human Rights
}

\section{TABLE OF CONTENTS}

\section{PROTOCOL}

PREAMBLE

CHAPTER I: MERGER OF THE AFRICAN COURT ON HUMAN AND PEOPLES' RIGHTS AND THE COURT OF JUSTICE OF THE AFRICAN UNION

Article 1 - Replacement of the 1998 and 2003 Protocols

Article 2 - Establishment of a Single Court

Article 3 - Reference to the single Court in the Constitutive Act

\section{CHAPTER II: TRANSITIONAL PROVISIONS}

Article 4 - Term of Office of the Judges of the African Court on Human and Peoples' Rights

Article 5 - Cases pending before the African Court of Human and Peoples Rights

Article 6 - Registry of the Court

Article 7 - Provisional Validity of the 1998 Protocol

CHAPTER III: FINAL PROVISIONS

Article 8 - Signature, Ratification and Accession

Article 9 - Entry into Force

\section{STATUTE OF THE AFRICAN COURT OF JUSTICE AND HUMAN RIGHTS}

\section{CHAPTER I: GENERAL PROVISIONS}

Article 1 - Definitions

Article 2 - Functions of the Court

\section{CHAPTER II: ORGANIZATION OF THE COURT}

Article 3 - Composition

Article 4 - Qualifications of Judges

Article 5 - Presentation of Candidates 
Article 6 - List of Candidates

Article 7 - Election of Judges

Article 8 - Term of Office

Article 9 - Resignation, Suspension and Removal from Office

Article 10 - Vacancies

Article 11 - Solemn Declaration

Article 12 - Independence

Article 13 - Conflict of Interest

Article14 - Conditions Governing the Participation of Judges in the Settlement of a Specified Case

Article 15 - Privileges and immunities

Article 16 - Sections of the Court

Article 17 - Assignment of matters to Sections

Article 18 - Referral of matters to the Full Court

Article 19 - Chambers

Article 20 - Sessions

Article 21 - Quorum

Article 22 - Presidency, Vice-Presidency and Registry

Article 23 - Remuneration of Judges

Article 24 - Conditions of Service of the Registrar and Members of the Registry

Article 25 - Seat and Seal of the Court

Article 26 - Budget

Article 27 - Rules of Court

\section{CHAPTER III: COMPETENCE OF THE COURT}

Article 28 - Jurisdiction of the Court

Article 29 - Entities eligible to Submit Cases to the Court

Article 30 - Other Entities Eligible to Submit Cases to the Court

Article 31 - Applicable Law 


\section{CHAPTER IV: PROCEDURE}

Article 32 - Official languages

Article 33 - Institution of Proceedings before the General Affairs Section

Article 34 - Institution of Proceedings before the Section on Human and Peoples' Rights

Article 35 - Provisional measures

Article 36 - Representation of Parties

Article 37 - Communications and Notices

Article 38 - Procedure before the Court

Article 39 - Public Hearing

Article 40 - Record of Proceedings

Article 41 - Default Judgment

Article 42 - Majority required for Decision of the Court

Article 43 - Judgments and Decisions

Article 44 - Dissenting opinion

Article 45 - Compensation

Article 46 - Binding Force and Execution of Judgments

Article 47 - Interpretation

Article 48 - Revision

Article 49 - Intervention

Article 50 - Intervention in a Case Concerning the Interpretation of the Constitutive Act

Article 51 - Intervention in a Case Concerning the Interpretation of other Treaties

Article 52 - Costs

\section{CHAPTER V: ADVISORY OPINIONS}

Article 53 - Request for Advisory Opinion

Article 54 - Service of Notice

Article 55 - Delivery of Advisory Opinion 
Article 56 - Application by analogy of the Provisions of the Statute applicable to Contentious cases

\section{CHAPTER VI - REPORT TO THE ASSEMBLY}

Article 57 - Annual Activity Report

\section{CHAPTER VII - PROCEDURE FOR AMENDMENTS}

Article 58 - Proposed Amendments from a State Party

Article 59 - Proposed Amendments from the Court

Article 60 - Entry into Force of Amendments

\section{PROTOCOL ON THE STATUTE OF THE AFRICAN COURT OF JUSTICE AND HUMAN RIGHTS}

The Member States of the African Union, Parties to this Protocol,

RECALLING the objectives and principles enunciated in the Constitutive Act of the African Union, adopted on 11 July 2000 in Lomé, Togo, in particular the commitment to settle their disputes through peaceful means;

BEARING IN MIND their commitment to promote peace, security and stability on the Continent and to protect human and peoples' rights in accordance with the African Charter on Human and Peoples' Rights and other relevant instruments relating to human rights;

CONSIDERING that the Constitutive Act of the African Union provides for the establishment of a Court of Justice charged with hearing, among other things, all cases relating to interpretation or application of the said Act or of all other Treaties adopted within the framework of the Union;

FURTHER CONSIDERING Decisions Assembly/AU/Dec.45 (III) and Assembly/ AU/Dec.83 (V) of the Assembly of the Union, adopted respectively at its Third (6-8 July 2004, Addis Ababa, Ethiopia) and Fifth (4-5 July 2005, Sirte, Libya), Ordinary Sessions, to merge the African Court on Human and Peoples' Rights and the Court of Justice of the African Union into a single Court,

FIRMLY CONVINCED that the establishment of an African Court of Justice and Human Rights shall assist in the achievement of the goals pursued by the African Union and that the attainment of the objectives of the African Charter on Human and Peoples' Rights requires the establishment of a judicial organ to supplement and strengthen the mission of the African Commission on Human and Peoples' Rights as well as the African Committee of Experts on the Rights and Welfare of the Child;

TAKING DUE ACCOUNT of the Protocol to the African Charter on Human and Peoples' Rights on the Establishment an African Court on Human and Peoples' 
Rights, adopted by the Assembly of Heads of States and Governments of the Organization of African Unity on 10 June 1998 at Ouagadougou, Burkina Faso, and which entered into force on 25 January 2004;

TAKING DUE ACCOUNT ALSO of the Protocol of the Court of Justice of the African Union, adopted by the Assembly of the Union on 11 July 2003 in Maputo Mozambique;

RECALLING their commitment to take all necessary measures to strengthen their common institutions and to endow them with the necessary powers and resources to carry out their missions effectively;

COGNIZANT of the Protocol to the African Charter on Human and Peoples' Rights on the Rights of Women in Africa, and the commitments contained in the Solemn Declaration on the gender equality in Africa (Assembly/AU/Decl.12 (III) adopted by the Assembly of the Union respectively at its Second and Third ordinary sessions held in July 2003 and 2004, in Maputo, Mozambique and in Addis Ababa, Ethiopia);

CONVINCED that the present Protocol shall supplement the mandate and efforts of other continental treaty bodies as well as national institutions in protecting human rights:

\section{HAVE AGREED AS FOLLOWS:}

\section{CHAPTER I: MERGER OF THE AFRICAN COURT ON HUMAN AND PEOPLES' RIGHTS AND THE COURT OF JUSTICE OF THE AFRICAN UNION}

\section{Article 1: Replacement of the 1998 and 2003 Protocols}

The Protocol to the African Charter on Human and Peoples' Rights on the Establishment of an African Court on Human and Peoples' Rights, adopted on 10 June 1998 in Ouagadougou, Burkina Faso and which entered into force on 25 January 2004, and the Protocol of the Court of Justice of the African Union, adopted on 11 July 2003 in Maputo, Mozambique, are hereby replaced by the present Protocol and Statute annexed as its integral part hereto, subject to the provisions of Article 5, 7 and 9 of this Protocol.

\section{Article 2: Establishment of a single Court}

The African Court on Human and Peoples' Rights established by the Protocol to the African Charter on Human and Peoples' Rights on the Establishment of an African Court on Human and Peoples' Rights and the Court of Justice of the African Union established by the Constitutive Act of the African Union, are hereby merged into a single Court and established as "The African Court of Justice and Human Rights". 


\section{Article 3: Reference to the single Court in the Constitutive Act}

References made to the "Court of Justice" in the Constitutive Act of the African Union shall be read as references to the "African Court of Justice and Human Rights" established under Article 2 of this Protocol.

\section{CHAPTER II: TRANSITIONAL PROVISIONS}

\section{Article 4: Term of Office of the Judges of the African Court on Human and Peoples' Rights}

The term of office of the Judges of the African Court on Human and Peoples' Rights shall end following the election of the Judges of the African Court of Justice and Human Rights. However, the Judges shall remain in office until the newly elected Judges of the African Court of Justice and Human Rights are sworn in.

\section{Article 5: Cases Pending before the African Court on Human and Peoples' Rights}

Cases pending before the African Court on Human and Peoples' Rights, that have not been concluded before the entry into force of the present Protocol, shall be transferred to the Human Rights Section of the African Court of Justice and Human Rights on the understanding that such cases shall be dealt with In accordance with the protocol to the ACHPR on the establishment of the African Court on Human and Peoples' Rights.

\section{Article 6: Registry of the Court}

The Registrar of the African Court on Human and Peoples' Rights shall remain in office until the appointment of a new Registrar for the African Court of Justice and Human Rights.

\section{Article 7: Provisional validity of the 1998 Protocol}

The Protocol to the African Charter on Human and Peoples' Rights on the Establishment of an African Court on Human and Peoples' Rights shall remain in force for a transitional period not exceeding one (1) year or any other period determined by the Assembly, after entry into force of the present Protocol, to enable the African Court on Human and Peoples' Rights to take the necessary measures for the transfer of its prerogatives, assets, rights and obligations to the African Court of Justice and Human Rights.

\section{CHAPTER III: FINAL PROVISIONS}

\section{Article 8: Signature, Ratification and Accession}

1. The present Protocol shall be open for signature, ratification or accession by Member States, in accordance with their respective constitutional procedures. 
2. The instruments of ratification or accession to the present Protocol shall be deposited with the Chairperson of the Commission of the African Union.

3. Any Member State may, at the time of signature or when depositing its instrument of ratification or accession, or at any time thereafter, make a declaration accepting the competence of the Court to receive cases under Article 30 (f) involving a State which has not made such a declaration.

\section{Article 9: Entry into force}

1. The present Protocol and the Statute annexed to it shall enter into force thirty (30) days after the deposit of the instruments of ratification by fifteen (15) Member States.

2. For each Member State which shall ratify or accede to it subsequently, the present Protocol shall enter into force on the date on which the instruments of ratification or accession are deposited,

3. The Chairperson of the Commission shall inform all Member States of the entry into force of the present Protocol.

ADOPTED BY THE ELEVENTH ORDINARY SESSION OF THE ASSEMBLY, HELD IN SHARM EL-SHEIKH, EGYPT, 1ST JULY 2008

\section{$\underline{\text { ANNEX }}$}

\section{STATUTE OF THE AFRICAN COURT OF JUSTICE AND HUMAN RIGHTS}

\section{CHAPTER I: GENERAL PROVISIONS}

\section{Article 1: Definitions}

In this Statute, except otherwise indicated, the following shall mean:

"African Charter" means the African Charter on Human and Peoples' Rights;

"African Commission" means the African Commission on Human and Peoples' Rights;

"African Committee of Experts" means the African Committee of Experts on the Rights and Welfare of the Child;

"African Intergovernmental Organisations" means an organisation that has been established with the aim of ensuring socio-economic integration, and to which some Member States have ceded certain competences to act on their behalf, as well as other sub-regional, regional or inter-African Organisations; 
“African Non-Governmental Organizations" means Non-Governmental Organizations at the sub-regional, regional or inter-African levels as well as those in the Diaspora as may be defined by the Executive Council;

"Agent" means a person mandated in writing to represent a party in a case before the Court;

"Assembly" means the Assembly of Heads of State and Government of the Union;

"Chamber(s)" means a Chamber established in accordance with Article 19 of the Statute.

"Constitutive Act" means the Constitutive Act of the African Union;

"Commission": means the Commission of the Union;

"Court" means the African Court of Justice and Human Rights as well as its sections and chambers;

"Executive Council" means the Executive Council of Ministers of the Union;

"Full Court" means joint sitting of the General Affairs and Human Rights Sections of the Court;

"Human Rights Section" means the Human and Peoples' Rights Section of the Court;

"Judge" means a judge of the Court;

"Member State" means a Member State of the Union;

"National Human Rights Institutions" means public institutions established by a state to promote and protect human rights;

"President" means the President of the Court elected in accordance with Article 22(1) of the Statute;

"Protocol" means the Protocol to the Statute of the African Court of Justice and Human Rights;

"Registrar" means the person appointed as such in accordance with Article 22 (4) of the Statute;

"Rules" means the Rules of the Court;

"Section" means the General Affairs or the Human Rights Section of the Court;

"Senior Judge" means the person defined as such in the Rules of Court;

"States Parties" means Member States, which have ratified or acceded to this Protocol; 
"Statute" means the present Statute;

"Union" means the African Union established by the Constitutive Act;

"Vice President" means the Vice President of the Court elected in accordance with Article 22 (1) of the Statute.

\section{Article 2: Functions of the Court}

1. The African Court of Justice and Human Rights shall be the main judicial organ of the African Union.

2. The Court shall be constituted and function in accordance with the provisions of the present Statute.

\section{CHAPTER II: ORGANIZATION OF THE COURT}

\section{Article 3: Composition}

1. The Court shall consist of sixteen (16) Judges who are nationals of States Parties. Upon recommendation of the Court, the Assembly, may, review the number of Judges.

2. The Court shall not, at any one time, have more than one judge from a single Member State.

3. Each geographical region of the Continent, as determined by the Decisions of the Assembly shall, where possible, be represented by three (3) Judges except the Western Region which shall have four (4) Judges.

\section{Article 4: Qualifications of Judges}

The Court shall be composed of impartial and independent Judges elected from among persons of high moral character, who possess the qualifications required in their respective countries for appointment to the highest judicial offices, or are juris-consults of recognized competence and experience in international law and / or, human rights law.

\section{Article 5: Presentation of Candidates}

1. As soon as the Protocol to this Statute enters into force, the Chairperson of the Commission shall invite each State Party to submit, in writing, within a period of ninety (90) days, candidatures to the post of judge of the Court.

2. Each State Party may present up to two (2) candidates and shall take into account equitable gender representation in the nomination process.

\section{Article 6: List of candidates}

1. For the purpose of election, the Chairperson of the Commission shall establish two alphabetical lists of candidates presented as follows: 
List A containing the names of candidates having recognized competence and experience in International law; and

ii List $\mathrm{B}$ containing the names of candidates possessing recognized competence and experience in Human Rights law.

2. States Parties that nominate candidates possessing the competences required on the two lists shall choose the list on which their candidates may be placed.

3. At the first election, eight (8) Judges shall be elected from amongst the candidates of list $\mathrm{A}$ and eight (8) from among the candidates of list $\mathrm{B}$. The elections shall be organized in a way as to maintain the same proportion of judges elected on the two lists.

4. The Chairperson of the Commission shall communicate the two lists to Member States, at least thirty (30) days before the Ordinary Session of the Assembly or of the Council, during which the elections shall take place.

\section{Article 7: Election of judges}

1. The Judges shall be elected by the Executive Council, and appointed by the Assembly.

2. They shall be elected through secret ballot by a two-thirds majority of Member States with voting rights, from among the candidates provided for in Article 6 of this Statute.

3. Candidates who obtain the two-thirds majority and the highest number of votes shall be elected. However, if several rounds of election are required, the candidates with the least number of votes shall withdraw.

4. The Assembly shall ensure that in the Court as a whole there is equitable representation of the regions and the principal legal traditions of the Continent.

5. In the election of the Judges, the Assembly shall ensure that there is equitable gender representation.

\section{Article 8: Term of Office}

1. The Judges shall be elected for a period of six (6) years and may be re-elected only once. However, the term of office of eight (8) judges, four (4) from each section, elected during the first election shall end after four (4) years.

2. The Judges, whose term of office shall end after the initial period of four (4) years, shall be determined for each section, by lot drawn by the Chairperson of the Assembly or the Executive Council, immediately after the first election.

3. A Judge, elected to replace another whose term of office has not expired, shall complete the term of office of his predecessor. 
4. All the Judges except the President and the Vice-President, shall perform their functions on a part-time basis.

\section{Article 9: Resignation, Suspension and Removal from Office}

1. A Judge may resign his/her position in writing addressed to the President for transmission to the Chairperson of the Assembly through the Chairperson of the Commission.

2. A Judge shall not be suspended or removed from office save, where, on the recommendation of two-thirds majority of the other members, he/she no longer meets the requisite conditions to be a Judge.

3. The President shall communicate the recommendation for the suspension or removal of a Judge to the Chairperson of the Assembly through the Chairperson of the Commission.

4. Such a recommendation of the Court shall become final upon its adoption by the Assembly.

\section{Article 10: Vacancies}

1. A vacancy shall arise in the Court under the following circumstances:

a Death;

b Resignation;

c Removal from office.

2. In the case of death or resignation of a Judge, the President shall immediately inform the Chairperson of the Assembly through the Chairperson of the Commission in writing, who shall declare the seat vacant.

3. The same procedure and consideration for the election of a Judge shall also be followed in filling the vacancies.

\section{Article 11: Solemn Declaration}

1. After the first election, the Judges shall, at the first session of the Court and in the presence of the Chairperson of the Assembly, make a Solemn Declaration as follows:

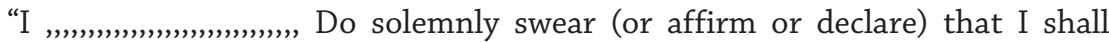
faithfully exercise the duties of my office as Judge of the African Court of Justice and Human Rights of the African Union impartially and conscientiously, without fear or favour, affection or ill will and that I will preserve the integrity of the Court.

2. The Chairperson of the Assembly or his/her duly authorized representative shall administer the Solemn Declaration. 
3. Subsequently, the Solemn Declaration shall be made before the President of the Court.

\section{Article 12: Independence}

1. The independence of the judges shall be fully ensured in accordance with international law.

2. The Court shall act impartially, fairly and justly.

3. In performance of the judicial functions and duties, the Court and its Judges shall not be subject to the direction or control of any person or body.

\section{Article 13: Conflict of Interest}

1. Functions of a Judge are incompatible with all other activities, which might infringe on the need for independence or impartiality of the judicial profession. In case of doubt, the Court shall decide.

2. A Judge shall not exercise the function of agent, or counsel, or lawyer in any case before the Court.

\section{Article 14: Conditions Governing the Participation of Members in the Settle- ment of a Specific Case}

1. Where a particular judge feels he/she has a conflicting interest in a particular case, he/she shall so declare. In any event, he/she shall not participate in the settlement of a case for which he/she was previously involved as agent, counsel or lawyer of one of the parties, or as a member of a national or international Court or Tribunal, or a Commission of enquiry or in any other capacity.

2. If the President considers that a Judge should not participate in a particular case, he/she shall notify the judge concerned. Such notification from the President shall, after agreement by the Court, exclude that Judge from participating in that particular case.

3. A Judge of the nationality of a State Party to a case before the full Court or one of its Sections shall not have the right to sit on the case.

4. Where there is doubt on these points, the Court shall decide.

\section{Article 15: Privileges and Immunities}

1. The Judges shall enjoy, from the time of their election and throughout their term of office, the full privileges and immunities extended to diplomatic agents in accordance with international law.

2. The Judges shall be immune from legal proceedings for any act or omission committed in the discharge of their judicial functions. 
3. The Judges shall continue, after they have ceased to hold office, to enjoy immunity in respect of acts performed by them when engaged in their official capacity.

\section{Article 16: Sections of the Court}

The Court shall have two (2) Sections; a General Affairs Section composed of eight (8) Judges and a Human Rights Section composed of eight (8) Judges.

\section{Article 17: Assignment of matters to Sections}

1. The General Affairs Section shall be competent to hear all cases submitted under Article 28 of this Statute save those concerning human and/or peoples' rights issues.

2. The Human Rights Section shall be competent to hear all cases relating to human and/or peoples rights.

\section{Article 18: Referral of matters to the Full Court}

When a Section of the Court is seized with a case, it may, if it deems it necessary refer that case to the Full Court for consideration.

\section{Article 19: Chambers}

1. The General Affairs Section and the Human Rights Section may, at any time, constitute one or several chambers. The quorum required to constitute such chambers shall be determined in the Rules of Court.

2. A judgment given by any Section or Chamber shall be considered as rendered by the Court.

\section{Article 20: Sessions}

1. The Court shall hold ordinary and extraordinary sessions.

2. The Court shall decide each year on the periods of its ordinary sessions.

3. Extraordinary sessions shall be convened by the President or at the request of the majority of the Judges.

\section{Article 21: Quorum}

1. A quorum of nine (9) Judges shall be required for deliberations of the Full Court.

2. A quorum of five (5) Judges shall be required for the deliberations of the General Affairs Section.

3. A quorum of five (5) Judges shall be required for the deliberations of the Human and Peoples' Rights Section. 


\section{Article 22: Presidency, Vice-Presidency and Registry}

1. At its first ordinary session after the election of the judges, the full Court shall elect its President as well as the Vice-President from the different lists for a period of three (3) years. The President and the Vice-President may be re-elected once.

2. The President shall preside over all sessions of the full Court and those of the Section to which he/she belongs; in the event of being unable to sit, the President shall be replaced by the Vice president for the full Court and by the most Senior Judge for the sessions of his/her Section.

3. The Vice-President shall preside over all sessions of the section to which he/she belongs. In the event of being unable to sit, the Vice-President shall be replaced by the most Senior Judge of that Section.

4. The Court shall appoint a Registrar and may provide for the appointment of such other officers as may be necessary.

5. The President, the Vice-President and the Registrar shall reside at the seat of the Court.

\section{Article 23: Remuneration of Judges}

1. The President and the Vice-President shall receive an annual salary and other benefits.

2. The other Judges shall receive a sitting allowance for each day on which he/she exercises his/her functions.

3. These salaries, allowances and compensation shall be determined by the Assembly, on the proposal of the Executive Council. They may not be decreased during the term of office of the Judges.

4. Regulations adopted by the Assembly on the proposal of the Executive Council shall determine the conditions under which retirement pensions shall be given to the Judges as well as the conditions under which their travel expenses shall be paid.

5. The above-mentioned salaries, allowances and compensation shall be free from all taxation.

Article 24: Conditions of Service of the Registrar and Members of the Registry

The salaries and conditions of service of the Registrar and other Court Officials shall be determined by the Assembly on the proposal of the Court, through the Executive Council. 


\section{Article 25: Seat and Seal of the Court}

1. The Seat of the Court shall be same as the Seat of the African Court on Human and Peoples' Rights. However, the Court may sit in any other Member State, if circumstances warrant, and with the consent of the Member State concerned. The Assembly may change the seat of the Court after due consultations with the Court.

2. The Court shall have a seal bearing the inscription "The African Court of Justice and Human Rights"

\section{Article 26: Budget}

1. The Court shall prepare its draft annual budget and shall submit it to the Assembly through the Executive Council.

2. The budget of the Court shall be borne by the African Union.

3. The Court shall be accountable for the execution of its budget and shall submit report thereon to the Executive Council in conformity with the Financial Rules and Regulations of the African Union.

\section{Article 27: Rules of Court}

1. The Court shall adopt rules for carrying out its functions and the implementation of the present Statute. In particular, it shall lay down its own Rules.

2. In elaborating its Rules, the Court shall bear in mind the complementarity it maintains with the African Commission and the African Committee of Experts.

\section{CHAPTER III: COMPETENCE OF THE COURT}

\section{Article 28: Jurisdiction of the Court}

The Court shall have jurisdiction over all cases and all legal disputes submitted to it in accordance with the present Statute which relate to:

a the interpretation and application of the Constitutive Act;

b the interpretation, application or validity of other Union Treaties and all subsidiary legal instruments adopted within the framework of the Union or the Organization of African Unity;

c the interpretation and the application of the African Charter, the Charter on the Rights and Welfare of the Child, the Protocol to the African Charter on Human and Peoples' Rights on the Rights of Women in Africa, or any other legal instrument relating to human rights, ratified by the States Parties concerned;

d any question of international law;

e all acts, decisions, regulations and directives of the organs of the Union;

$\mathrm{f} \quad$ all matters specifically provided for in any other agreements that States Parties may conclude among themselves, or with the Union and which confer jurisdiction on the Court; 
the existence of any fact which, if established, would constitute a breach of an obligation owed to a State Party or to the Union;

$h$ the nature or extent of the reparation to be made for the breach of an international obligation.

\section{Article 29: Entities Eligible to Submit Cases to the Court}

1. The following entities shall be entitled to submit cases to the Court on any issue or dispute provided for in Article 28:

a State Parties to the present Protocol;

b The Assembly, the Parliament and other organs of the Union authorized by the Assembly;

c A staff member of the African Union on appeal, in a dispute and within the limits and under the terms and conditions laid down in the Staff Rules and Regulations of the Union;

2. The Court shall not be open to States, which are not members of the Union. The Court shall also have no jurisdiction to deal with a dispute involving a Member State that has not ratified the Protocol.

\section{Article 30: Other Entities Eligible to Submit Cases to the Court}

The following entities shall also be entitled to submit cases to the Court on any violation of a right guaranteed by the African Charter, by the Charter on the Rights and Welfare of the Child, the Protocol to the African Charter on Human and Peoples' Rights on the Rights of Women in Africa, or any other legal instrument relevant to human rights ratified by the States Parties concerned:

a State Parties to the present Protocol;

b the African Commission on Human and Peoples' Rights;

c the African Committee of Experts on the Rights and Welfare of the Child;

d African Intergovernmental Organizations accredited to the Union or its organs;

e African National Human Rights Institutions;

f Individuals or relevant Non-Governmental Organizations accredited to the African Union or to its organs, subject to the provisions of Article 8 of the Protocol.

\section{Article 31: Applicable Law}

1. In carrying out its functions, the Court shall have regard to:

a The Constitutive Act;

b International treaties, whether general or particular, ratified by the contesting States;

c International custom, as evidence of a general practice accepted as law;

d The general principles of law recognized universally or by African States;

e Subject to the provisions of paragraph 1, of Article 46 of the present Statute, judicial decisions and writings of the most highly qualified publicists of 
various nations as well as the regulations, directives and decisions of the Union, as subsidiary means for the determination of the rules of law;

f Any other law relevant to the determination of the case.

2. This Article shall not prejudice the power of the Court to decide a case ex aequo et bono, if the parties agree thereto.

\section{CHAPTER IV: PROCEDURE}

\section{Article 32: Official Languages}

The official and working languages of the Court shall be those of the Union.

\section{Article 33: Institution of Proceedings before the General Affairs Section}

1. Cases brought before the Court by virtue of Article 29 of the present Statute shall be submitted by written application addressed to the Registrar. The subject of the dispute, the applicable law and basis of jurisdiction shall be indicated.

2. The Registrar shall forthwith give notice of the application to the Parties concerned.

3. The Registrar shall also notify, through the Chairperson of the Commission, all Member States and, if necessary, the organs of the Union whose decisions are in dispute.

\section{Article 34: Institution of Proceedings before the Human Rights Section}

1. Cases brought before the Court relating to an alleged violation of a human or peoples' right shall be submitted by a written application to the Registrar. The application shall indicate the right(s) alleged to have been violated, and, insofar as it is possible, the provision or provisions of the African Charter on Human and Peoples' Rights, the Charter on the Rights and Welfare of the Child, Protocol to the African Charter on Human and Peoples' Rights on the Rights of Women in Africa or any other relevant human rights instrument, ratified by the State concerned, on which it is based.

2. The Registrar shall forthwith give notice of the application to all parties concerned, as well as the Chairperson of the Commission.

\section{Article 35: Provisional Measures}

1. The Court shall have the power, on its own motion or on application by the parties, to indicate, if it considers that circumstances so require any provisional measures which ought to be taken to preserve the respective rights of the parties.

2. Pending the final decision, notice of the provisional measures shall forthwith be given to the parties and the Chairperson of the Commission, who shall inform the Assembly. 


\section{Article 36: Representation of Parties}

1. The States, parties to a case, shall be represented by agents.

2. They may, if necessary, have the assistance of counsel or advocates before the Court.

3. The organs of the Union entitled to appear before the Court shall be represented by the Chairperson of the Commission or his /her representative.

4. The African Commission, the African Committee of Experts, African InterGovernmental Organizations accredited to the Union or its organs and African National Human Rights Institutions entitled to appear before the Court shall be represented by any person they choose for that purpose.

5. Individuals and Non-Governmental Organizations accredited to the Union or its organs may be represented or assisted by a person of their choice.

6. The agents and other representatives of parties before the Court, their counsel or advocates, witnesses, and any other persons whose presence is required at the Court shall enjoy the privileges and immunities necessary to the independent exercise of their duties or the smooth functioning of the Court.

\section{Article 37: Communications and Notices}

1. Communications and notices addressed to agents or counsel of parties to a case shall be considered as addressed to the parties.

2. For the service of all communications or notices upon persons other than the agents, counsel or advocates of parties concerned, the Court shall direct its request to the government of the State upon whose territory the communication or notice has to be served.

3. The same provision shall apply whenever steps are to be taken to procure evidence on the spot.

\section{Article 38: Procedure Before the Court}

The procedures before the Court shall be laid out in the Rules of Court, taking into account the complementarity between the Court and other treaty bodies of the Union.

\section{Article 39: Public Hearing}

The hearing shall be public, unless the Court, on its own motion or upon application by the parties, decides that the session shall be closed.

\section{Article 40: Record of Proceedings}

1. A record of proceedings shall be made at each hearing and shall be signed by the Registrar and the presiding Judge of the session. 
2. This record alone shall be authentic.

\section{Article 41: Default Judgment}

1. Whenever one of the parties does not appear before the Court, or fails to defend the case against it, the Court shall proceed to consider the case and to give its judgment.

2. The Court shall before doing so, satisfy itself, not only that it has jurisdiction in accordance with Articles 28, 29 and 30 of the present Statute, but also that the claim is well founded in fact and law, and that the other party had due notice.

3. An objection by the party concerned may be lodged against the judgment within ninety (90) days of it being notified of the default judgment. Unless there is a decision to the contrary by the Court, the objection shall not have effect of staying the enforcement of the default judgment.

\section{Article 42: Majority Required for Decision of the Court}

1. Without prejudice to the provisions of Article 50(4) of the present Statute, the decisions of the Court shall be decided by a majority of the Judges present.

2. In the event of an equality of votes, the presiding Judge shall have a casting vote.

\section{Article 43: Judgments and Decisions}

1. The Court shall render its judgment within ninety (90) days of having completed its deliberations.

2. All judgments shall state the reasons on which they are based.

3. The judgment shall contain the names of the Judges who have taken part in the decision.

4. The judgment shall be signed by all the Judges and certified by the Presiding Judge and the Registrar. It shall be read in open session, due notice having been given to the agents.

5. The Parties to the case shall be notified of the judgment of the Court and it shall be transmitted to the Member States and the Commission.

6. The Executive Council shall also be notified of the judgment and shall monitor its execution on behalf of the Assembly

\section{Article 44: Dissenting Opinion}

If the judgment does not represent in whole or in part the unanimous opinion of the Judges, any Judge shall be entitled to deliver a separate or dissenting opinion. 


\section{Article 45: Compensation}

Without prejudice to its competence to rule on issues of compensation at the request of a party by virtue of paragraph 1(h), of Article 28 of the present Statute, the Court may, if it considers that there was a violation of a human or peoples' right, order any appropriate measures in order to remedy the situation, including granting fair compensation.

\section{Article 46: Binding Force and Execution of Judgments}

1. The decision of the Court shall be binding on the parties.

2. Subject to the provisions of paragraph 3, Article 41 of the present Statute, the judgment of the Court is final.

3. The parties shall comply with the judgment made by the Court in any dispute to which they are parties within the time stipulated by the Court and shall guarantee its execution.

4. Where a party has failed to comply with a judgment, the Court shall refer the matter to the Assembly, which shall decide upon measures to be taken to give effect to that judgment.

5. The Assembly may impose sanctions by virtue of paragraph 2 of Article 23 of the Constitutive Act.

\section{Article 47: Interpretation}

In the event of any dispute as to the meaning or scope of a judgment, the Court shall construe it upon the request of any party.

\section{Article 48: Revision}

1. An application for revision of a judgment may be made to the Court only when it is based upon discovery of a new fact of such nature as to be a decisive factor, which fact was, when the judgment was given, unknown to the Court and also to the party claiming revision, provided that such ignorance was not due to negligence.

2. The proceedings for revision shall be opened by a ruling of the Court expressly recording the existence of the new fact, recognizing that it has such a character as to lay the case open to revision, and declaring the revision admissible on this ground.

3. The Court may require prior compliance with the terms of the judgment before it admits proceedings in revision.

4. The application for revision shall be made within six (6) months of the discovery of the new fact. 
5. No application may be made after the lapse of ten (10) years from the date of the judgment.

\section{Article 49: Intervention}

1. Should a Member State or organ of the Union consider that it has an interest of a legal nature which may be affected by the decision in the case, it may submit a request to the Court to be permitted to intervene. It shall be for the Court to decide upon this request.

2. If a Member State or organ of the Union should exercise the option offered under paragraph 1 of the present Article, the interpretation contained in the decision shall be equally binding upon it.

3. In the interest of the effective administration of justice, the Court may invite any Member State that is not a party to the case, any organ of the Union or any person concerned other than the claimant, to present written observations or take part in hearings.

Article 50: Intervention in a Case Concerning the Interpretation of the Constitutive Act

1. Whenever the question of interpretation of the Constitutive Act arises, in a case in which Member States other than the parties to the dispute have expressed an interest, the Registrar shall notify all such States and organs of the Union forthwith.

2. Every State Party and organ of the Union so notified has the right to intervene in the proceedings.

3. The decisions of the Court concerning the interpretation and application of the Constitutive Act shall be binding on Member States and organs of the Union, notwithstanding the provisions of paragraph 1, of Article 46 of this Statute.

4. Any decision made by virtue of this Article shall be made by a qualified majority of at least two (2) votes and in the presence of at least two-thirds of the Judges.

Article 51: Intervention in a Case concerning the Interpretation of Other Treaties

1. Whenever the question is that of interpretation of other treaties ratified by Member States other than the parties to a dispute, the Registrar shall notify all such States and the organs of the Union forthwith.

2. Every State Party and organ of the Union so notified has the right to intervene in the proceedings, and if it exercises this right, the interpretation given by the judgment shall be equally binding upon it. 
3. This Article shall not be applicable to cases relating to alleged violations of a human or peoples' right, submitted by virtue of Articles 29 or 30 of the present Statute.

\section{Article 52: Costs}

1. Unless otherwise decided by the Court, each party shall bear its own costs.

2. Should it be required in the interest of justice, free legal aid may be provided for the person presenting an individual communication, under conditions to be set out in the Rules of Court.

\section{CHAPTER V: ADVISORY OPINION}

\section{Article 53: Request for Advisory Opinion}

1. The Court may give an advisory opinion on any legal question at the request of the Assembly, the Parliament, the Executive Council, the Peace and Security Council, the Economic, Social and Cultural Council (ECOSOCC), the Financial Institutions or any other organ of the Union as may be authorized by the Assembly.

2. A request for an advisory opinion shall be in writing and shall contain an exact statement of the question upon which the opinion is required and shall be accompanied by all relevant documents.

3. A request for an advisory opinion must not be related to a pending application before the African Commission or the African Committee of Experts.

\section{Article 54: Service of Notice}

1. The Registrar shall forthwith give notice of the request for an advisory opinion to all States or organs entitled to appear before the Court by virtue of Article 30 of the present Statute.

2. The Registrar shall also, by means of a special and direct communication, notify any State entitled to appear before the Court or any Intergovernmental Organization considered by the Court, or should it not be sitting, by the President, as likely to be able to furnish information on the question, that the Court will be prepared to receive, within a time limit to be fixed by the President, written statements, or to hear, at a public sitting to be held for the purpose, oral statements relating to the question.

3. Should any such State entitled to appear before the Court have failed to receive the special communication referred to in paragraph 2 of this Article, such State may express the desire to submit a written statement or to be heard, and the Court shall decide.

4. States and organizations having presented written or oral statements or both shall be permitted to comment on the statements made by other States or organi- 
zations in the form, to the extent, and within the time limits which the Court, or should it not be sitting, the President, shall decide in each particular case. Accordingly, the Registrar shall in due course communicate any such written statements to States and organizations having submitted similar statements.

\section{Article 55: Delivery of Advisory Opinion}

The Court shall deliver its advisory opinion in open court, notice having been given to the Chairperson of the Commission and Member States, and other International Organizations directly concerned.

Article 56: Application by Analogy of the Provisions of the Statute Applicable to Contentious Cases

In the exercise of its advisory functions, the Court shall further be guided by the provisions of the present Statute which apply in contentious cases to the extent to which it recognizes them to be applicable.

\section{CHAPTER VI: REPORT TO THE ASSEMBLY}

\section{Article 57: Annual Activity Report}

The Court shall submit to the Assembly, an annual report on its work during the previous year. The report shall specify, in particular, the cases in which a party has not complied with the judgment of the Court.

\section{CHAPTER VII: PROCEDURE FOR AMENDMENTS}

\section{Article 58: Proposed Amendments from a State Party}

1. The present Statute may be amended if a State Party makes a written request to that effect to the Chairperson of the Commission, who shall transmit same to Member States within thirty (30) days of receipt thereof.

2. The Assembly may adopt by a simple majority, the proposed amendment after the Court has given its opinion on it.

\section{Article 59: Proposed Amendments from the Court}

The Court may propose such amendments to the present Statute as it may deem necessary, to the Assembly through written communication to the Chairperson of the Commission, for consideration in conformity with the provisions of Article 58 of the present Statute.

\section{Article 60: Entry into Force of Amendments}

The amendment shall enter into force for every State which has accepted it in conformity with its Constitutional laws thirty (30) days after the Chairperson of the Commission is notified of this acceptance. 